\title{
Simple rapid in vitro screening method for SARS-CoV-2 anti-virals that identifies potential cytomorbidity-associated false positives
}

\author{
Kexin Yan ${ }^{1 \dagger}$, Daniel J. Rawle ${ }^{1 \dagger}$, Thuy T. Le ${ }^{1}$ and Andreas Suhrbier ${ }^{1,2^{*}}$ (D)
}

\begin{abstract}
Background: The international SARS-CoV-2 pandemic has resulted in an urgent need to identify new anti-viral drugs for treatment of COVID-19. The initial step to identifying potential candidates usually involves in vitro screening that includes standard cytotoxicity controls. Under-appreciated is that viable, but stressed or otherwise compromised cells, can also have a reduced capacity to replicate virus. A refinement proposed herein for in vitro drug screening thus includes a simple growth assay to identify drug concentrations that cause cellular stress or "cytomorbidity", as distinct from cytotoxicity or loss of viability.

Methods: A simple rapid bioassay is presented for antiviral drug screening using Vero E6 cells and inhibition of SARSCoV-2 induced cytopathic effects (CPE) measured using crystal violet staining. We use high cell density for cytotoxicity assays, and low cell density for cytomorbidity assays.

Results: The assay clearly illustrated the anti-viral activity of remdesivir, a drug known to inhibit SARS-CoV-2 replication. In contrast, nitazoxanide, oleuropein, cyclosporine A and ribavirin all showed no ability to inhibit SARS-CoV-2 CPE. Hydroxychloroquine, cyclohexamide, didemnin $B, \gamma$-mangostin and linoleic acid were all able to inhibit viral CPE at concentrations that did not induce cytotoxicity. However, these drugs inhibited CPE at concentrations that induced cytomorbidity, indicating non-specific anti-viral activity.

Conclusions: We describe the methodology for a simple in vitro drug screening assay that identifies potential antiviral drugs via their ability to inhibit SARS-CoV-2-induced CPE. The additional growth assay illustrated how several drugs display anti-viral activity at concentrations that induce cytomorbidity. For instance, hydroxychloroquine showed anti-viral activity at concentrations that slow cell growth, arguing that its purported in vitro anti-viral activity arises from non-specific impairment of cellular activities. The cytomorbidity assay can therefore rapidly exclude potential false positives.
\end{abstract}

Keywords: SARS-CoV-2, Drug screening, Cytopathic effect, Cytotoxicity, Cytomorbidity

*Correspondence: Andreas.Suhrbier@qimrberghofer.edu.au

† Kexin Yan and Daniel J. Rawle contributed equally and should be considered joint first

${ }^{1}$ QIMR Berghofer Medical Research Institute, Brisbane, QLD 4029, Australia

Full list of author information is available at the end of the article

\section{Main text}

The global SARS-CoV-2 pandemic has resulted in widespread activities seeking to identify new anti-viral drugs that might be used to treat COVID-19 patients [1-5]. Remdesivir has emerged as a lead candidate with clear anti-viral activity in vitro [6] and non-human primates 
[7], with results in human trials suggesting benefit, although mortality remained high $[8,9]$. The quest for new anti-viral drugs for SARS-CoV-2 (as for other viruses) usually begins with in vitro screening to identify potential candidates [10-12]. Initial screening usually involves assessing whether drugs can inhibit virus replication in a permissive cell line, with Vero E6 cells widely used for SARS-CoV-2. Such in vitro screening approaches often identify drugs that work well in vitro, but ultimately fail to have anti-viral activity in vivo. For example, chloroquine/hydroxychloroquine inhibits SARS-CoV-2 replication in vitro $[6,13,14]$, but the drug ultimately emerged to have no utility in COVID19 patients [15-17]. Chloroquine/hydroxychloroquine was similarly shown to have in vitro antiviral activity, but no anti-viral activity in humans for a number of viruses including Epstein Barr virus (infectious mononucleosis) [18], dengue [19], HIV [20], chikungunya [21], Ebola [22] and influenza [23].

Although there are multiple reasons why in vitro antiviral activity often does not translate into in vivo efficacy, one reason for false positives from in vitro screening assays is the misapplication of the therapeutic index concept as it applies to tissue culture-based anti-viral drug discovery, where this index is generally referred to as the selectivity index. The concentration of a drug that inhibits virus replication is often compared to the concentration that kills the cells (cytotoxicity). The MTS assay is also often used as a cytotoxicity or viability assay, although it actually measures mitochondrial activity. Differences in conclusions from MTS and other cytotoxicity assays are common [24], leading some to suggest complex combined cytotoxicity assays [25], which are not readily compatible with rapid screening under BSL3 containment conditions [26]. Viral replication would clearly be inhibited in cells that are not viable; however, what is perhaps under-appreciated is that viable, but stressed or otherwise slightly poisoned or compromised cells, are also likely to have a reduced capacity to replicate virus. Cellular stress responses can take multiple forms, but a key outcome of most stress responses is inhibition of translation [27-31]. Translational inhibition is also a key anti-viral response, which is able to inhibit replication of many viruses [27, 30, 32] including coronaviruses [33]. A drug that has no specific anti-viral activity, but induces cellular stress, may therefore inhibit virus replication non-specifically and generate a potential false positive in screening assays. We coin the term "cytomorbidity" to describe this phenomenon and describe herein a simple growth assay that can be used to distinguish cytomorbidity from cytotoxicity, and argue that both cytomorbidity and cytotoxicity controls are needed to increase the reliability and stringency of in vitro drug screening assays.
A key outcome of stress responses is usually to slow cell growth, allowing the cell to either recover, or if stress and/or damage is excessive, to induce cell death [34-36]. Cells that are slightly poisoned or otherwise compromised (without induction of stress responses) would likely also show reduced growth rates. Cell growth of Vero E6 cells can be very simply measured by seeding 400 cells per well in 96 well flat bottom plates and culturing with a range of drug concentrations for 4 days followed by crystal violet staining. Vero E6 cells (C1008, ECACC, Wiltshire, England; Sigma Aldrich, St. Louis, MO, USA) were plated at $4 \times 10^{2}$ (cytomorbidity assay) or $10^{4}$ (antiviral screening, cytotoxicity assay and MTS assay) cells per well in a 96 well plate in $100 \mu \mathrm{l}$ medium and cultured overnight at $37{ }^{\circ} \mathrm{C}$ and $5 \% \mathrm{CO}_{2}$. The drug (at 4 times the indicated final concentration) was diluted in twofold serial dilutions in RPMI 1640 supplemented with 2\% FCS in a 96 well round bottom plate, and $50 \mu \mathrm{l}$ was then transferred to cells using a multichannel pipette. For antiviral screening assay, SARS-CoV-2 (hCoV-19/Australia/ QLD02/2020 [37], kindly provided by Queensland Health Forensic and Scientific Services, Queensland Department of Health, Brisbane, Australia) was diluted in RPMI 1640 supplemented with $2 \%$ FCS to a final concentration of $2 \times 10^{3} \mathrm{CCID}_{50} / \mathrm{ml}$ and $50 \mu \mathrm{l}$ was added per well using a multichannel pipette for a final MOI $\sim 0.01$. For cytomorbidity or cytotoxicity assay, $50 \mu \mathrm{l}$ RPMI 1640 supplemented with $2 \%$ FCS (instead of virus) was then added per well to give a final volume of $200 \mu$ at the desired drug concentration. The plates were cultured for 4 days at $37{ }^{\circ} \mathrm{C}$ and $5 \% \mathrm{CO}_{2}$. To inactivate virus and stain the cells, $50 \mu \mathrm{l}$ of formaldehyde $(15 \% \mathrm{w} / \mathrm{v})$ and crystal violet $(0.1 \%$ $\mathrm{w} / \mathrm{v}$ ) (Sigma-Aldrich) was added per well to the $200 \mu \mathrm{l}$ of medium already present in each well. After washing and drying, stain was dissolved in $100 \%$ methanol and the OD was read at $595 \mathrm{~nm}$. The percentage of protein staining relative to a no-drug control was then calculated. The MTS assay was performed in duplicate where indicated using CellTiter 96 AQueous One Solution Cell Proliferation Assay (MTS) (Promega) as per manufacturer's instructions.

Perhaps not surprisingly the drug concentrations that caused inhibition of cell growth were usually lower than the drug concentrations that caused cytotoxicity (Fig. 1, compare black circles with green squares). For some drugs the concentration differences for these two activities were $\geq$ tenfold (Fig. 1, ribavirin, cycloheximide, oleuropein, didemnin B). Inhibition of cell growth is not really cytostasis, which generally means no growth, and not really cytotoxicity, which is generally viewed as cell death. The reason(s) for reduced cell growth induced by any given drug may not be clear, and may be related to stress responses or some other 


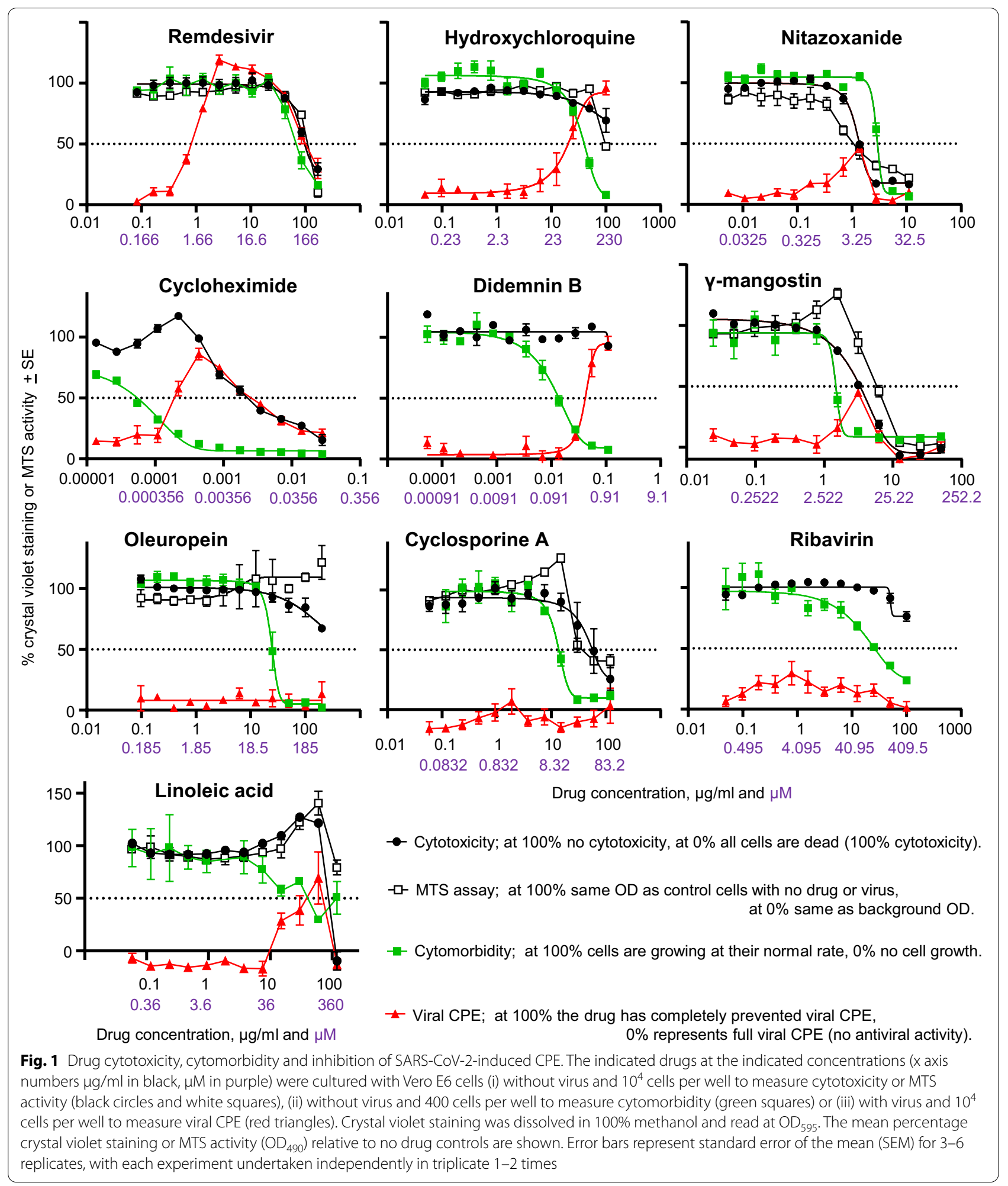

phenomena that compromises the cells normal metabolic activities. Hence we suggest the term "cytomorbidity" to infer a level of cytotoxicity insufficient to kill the cells or induce cytostasis, but sufficient to stress or compromise the cells, with a simple growth bioassay used to indicate cytomorbidity. The cytomorbidity 
assay proposed herein, although considerably simpler, is not dissimilar in principle to a previously published cell proliferation assay used as a control for drug screening [38].

A simple rapid bioassay for screening drugs for potential anti-viral activity against SARS-CoV-2 is to determine whether the drug can inhibit virus-induced cytopathic effects (CPE) in Vero E6 cells. Remdesivir is known to inhibit SARS-CoV-2 replication [6] and is used herein to illustrate the behavior of an effective drug in this bioassay. Remdesivir was able to inhibit virusinduced CPE by $50 \%$ at $\approx 1 \mu \mathrm{g} / \mathrm{ml}$ and the drug caused $50 \%$ cytotoxicity at $\approx 100 \mu \mathrm{g} / \mathrm{ml}$, providing a selectivity index of $\approx 100$. Importantly, remdesivir showed cytomorbidity at $\approx 70 \mu \mathrm{g} / \mathrm{ml}$, which still leaves a selectivity index of $\approx 70$ (Figs. 1, 2, Table 1, Remdesivir). Hydroxychloroquine was able to inhibit viral CPE by $50 \%$ at $\approx 20 \mu \mathrm{g} / \mathrm{ml}$ and showed a $50 \%$ loss of viability using the MTS assay at $\approx 100 \mu \mathrm{g} / \mathrm{ml}$, suggesting a selectivity index of $\approx 5$. However, cytomorbidity was clearly evident at $\approx 40 \mu \mathrm{g} /$ $\mathrm{ml}$, so the anti-viral activity occurred at similar concentrations to those that caused cytomorbidity (Fig. 1, Table 1, Hydroxychloroquine); indicating a potential false positive. The overlapping activities are clearly evident when the crystal violet stained plates are viewed (Fig. 2).

The close relationship between anti-viral activity and translation inhibition (inherent in the stress responses described above) can be seen with the use of the translation inhibitors, cycloheximide and didemnin B. These drugs provide selectivity indices of $\geq 10$, when comparing viral CPE inhibition and cytotoxicity. However, concentrations that inhibited viral CPE again overlapped with those that caused cytomorbidity (Fig. 1, Cycloheximide, Didemnin B). The drug $\gamma$-mangostin would appear to have a small level of anti-viral activity with a low selectivity index, but again this activity overlapped with the cytomorbidity (Fig. 1, $\gamma$-mangostin). Linoleic acid is reported to contribute to anti-viral activity at $50 \mu \mathrm{M}$ [39]; however, this drug shows clear cytomorbidity activity above $\approx 20 \mu \mathrm{M}$ (Fig. 1, Linoleic acid). Thus, as for hydroxychloroquine, the assay results for these latter drugs provide no supportive data for anti-viral activity, instead they suggest these drugs inhibit viral replication nonspecifically by impairing cellular activities. Nitazoxanide showed some anti-viral activity, but this coincided with cytotoxicity, providing an example of the conventional

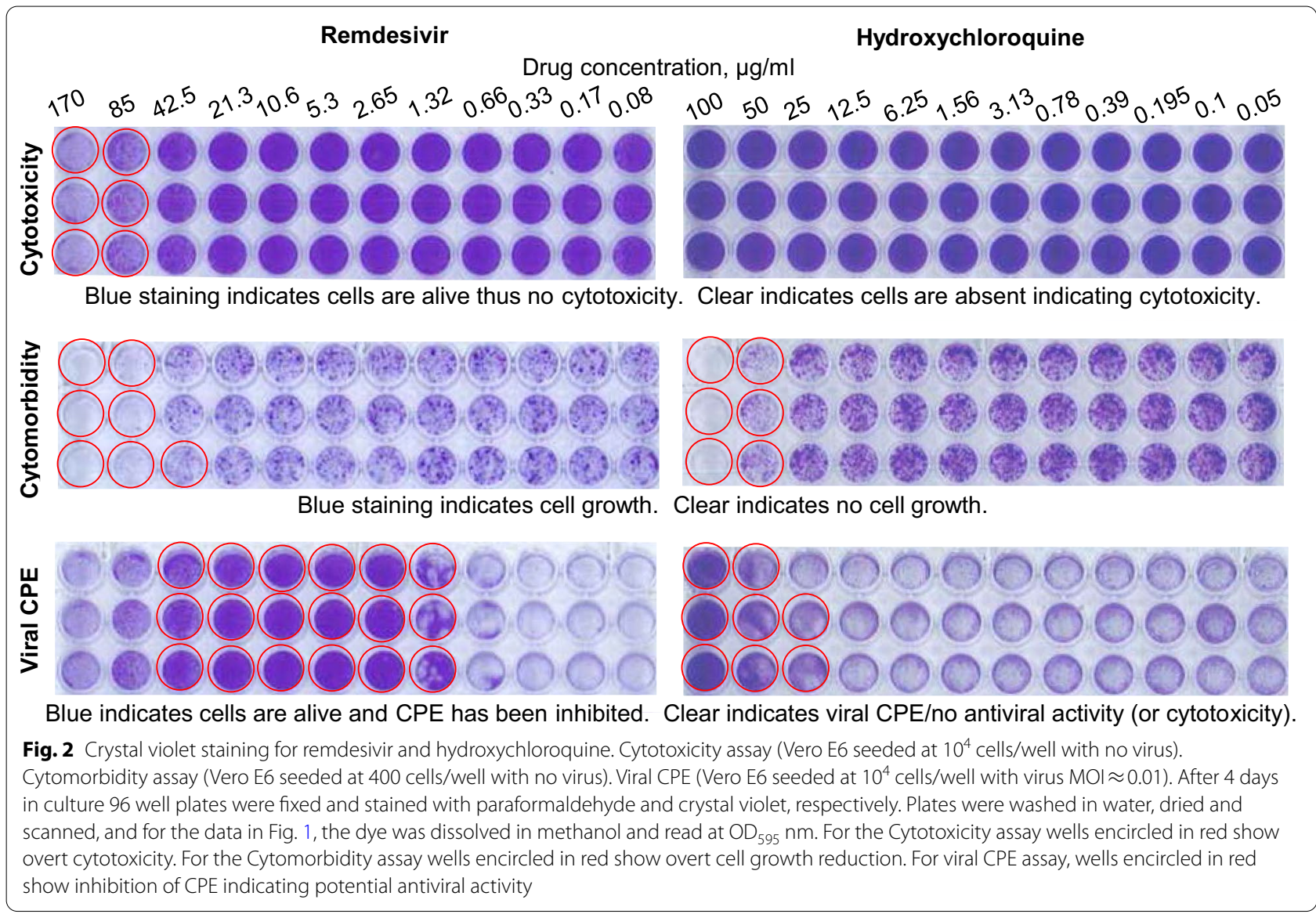


Table 1 The half maximal inhibitory dose (IC50), half maximal cytotoxic concentration (CC50), and half maximal cytomorbidity concentration (MC50) for each compound

\begin{tabular}{|c|c|c|c|c|c|c|}
\hline Drug name & IC50 $(\mu \mathrm{g} / \mathrm{ml})$ & IC50 (uM) & $\mathrm{CC} 50(\mu \mathrm{g} / \mathrm{ml})$ & $\mathrm{CC} 50(\mu \mathrm{M})$ & MC50 $(\mu \mathrm{g} / \mathrm{ml})$ & MC50 $(\mu \mathrm{M})$ \\
\hline Hydroxychloroquine & 19 & 43.78 & NA & NA & 39.8 & 91.72 \\
\hline Nitazoxanide & NA & NA & 1.36 & 4.43 & 2.82 & 9.18 \\
\hline Oleuropein & NA & NA & NA & NA & 24 & 44.40 \\
\hline Gamma-mangostin & NA & NA & 3.31 & 8.35 & 1.47 & 3.70 \\
\hline DidemninB & 0.04 & 0.36 & NA & NA & 0.013 & 0.12 \\
\hline Cycloheximide & 0.0002 & 0.0007 & 0.0022 & 0.0078 & 0.000054 & 0.00019 \\
\hline Remdesivir & 0.83 & 1.38 & 96.2 & 159.64 & 67.3 & 111.68 \\
\hline Ribavirin & NA & NA & NA & NA & 26.1 & 106.88 \\
\hline CyclosporineA & NA & NA & 57.3 & 47.65 & 13.6 & 11.31 \\
\hline Linoleic acid & 17.7 & 63.9 & 40.2 & 144.9 & 18.2 & 65.6 \\
\hline
\end{tabular}

cytotoxicity control that would be used to argue that the drug has no specific anti-viral activity and has a selectivity index of 1 (Fig. 1, Nitazoxanide). Curiously, higher concentrations of nitazoxanide were needed to inhibit cell growth than were needed to induce cytotoxicity; likely an example of cell density associated toxicity.

The frequently used MTS assay, as expected, often gave results similar to those provided by the cytotoxicity assay. Importantly, the MTS assay did not provide a measure of cytomorbidity, presumably because mitochondria largely remain active even in stressed cells and/ or cells in $\mathrm{G}_{0}$ (cytostasis). For oleuropein, cyclosporine A and $\gamma$-mangostin, cytomorbidity was associated with an increase in MTS activity (Fig. 1). The MTS bioassay may thus provide slightly misleading information in this context; i.e. increased mitochondrial activity, rather than indicating increased cell numbers, can sometimes be associated with stress or mild toxicity.

The CPE-based assay described herein has some inherent limitations. Drugs whose mechanism of action require induction of type I interferons, would be ineffective in this assay system as Vero E6 cells do not make type I interferons. The CPE-based assay also provides a low sensitivity read-out. Higher drug concentrations are likely needed to prevent virus-induced CPE (overwhelming infection resulting in cell death) than would be needed to inhibit viral replication as measured (for instance) by qRT-PCR of virus released into culture supernatants [40]. Although more sensitive anti-viral activities exist [40], the CPE-based assay represents a screening tool able rapidly and cheaply to identify promising anti-viral candidates. More sensitive assays could be also envisaged for assessing cytomorbidity, such as measuring activation of stress factors such as ATF3 [41], analyzing cell cycle perturbations by flow cytometry or cell growth kinetics using the IncuCyte live-cell analysis system. The cell line used herein, Vero E6, is a monkey kidney-derived cell line, whereas in humans ciliated airway cells and alveolar type II pneumocytes (AT-2 cells) are thought to be the primary targets for SARS-CoV-2 infection [42]. Drug metabolism and/or bioavailability in such cells may not be reflected in Vero E6 cells. However, although a number of human cell lines support SARS-CoV-2 infection, few if any exhibit the fulminant CPE seen in Vero E6 cells [43].

\section{Conclusions}

In conclusion, in vitro screening of anti-SARS-CoV-2 drugs should include not just a cytotoxicity control, but also a cytomorbidity control in order to identify potential false positives associated with anti-viral activity arising from non-specific stress responses or other disruptions of cellular activities/functions.

\section{Abbreviations}

CPE: Cytopathic effects; HIV: Human immunodeficiency virus; MTS: 3-(4,5-Dimethylthiazol-2-yl)-5-(3-carboxymethoxyphenyl)-2-(4-sulfophenyl)2H-tetrazolium; BSL3: Biosafety level 3; RPMI: Roswell Park Memorial Institute medium; FCS: Fetal calf serum; CCID50: Cell culture infectious dose 50\%; OD: Optical absorbance; qRT-PCR: Real-time quantitative reverse-transcriptase polymerase chain reaction.

\section{Supplementary Information}

The online version contains supplementary material available at https://doi. org/10.1186/s12985-021-01587-z.

Additional file 1. Extended methods.

\section{Acknowledgements}

We thank Dr. I Anraku for his assistance in managing the PC3 (BSL3) facility at QIMR Berghofer MRI. We thank Dr. Alyssa Pyke and Mr Fredrick Moore (Queensland Health, Brisbane) for providing the SARS-CoV-2 virus. We thank Dr. David Harrich for help with reagents. 


\section{Authors' contributions}

KY and TTL undertook the experiments. DJR, AS supervised the experiments, analyzed the data and obtained funding. AS: wrote the manuscript with input from DJR. All authors read and approved the final manuscript.

\section{Funding}

We thank Clive Berghofer and the Brazil Family Foundation (and many others) for their generous philanthropic donations to support SARS-CoV-2 research at QIMR Berghofer MRI. A.S. holds an Investigator grant from the National Health and Medical Research Council (NHMRC) of Australia (APP1173880).

\section{Availability of data and materials}

All data generated or analysed during this study are included in this published article and its Additional file 1.

\section{Declarations}

\section{Ethics approval and consent to participate}

Not applicable.

\section{Consent for publication}

Not applicable.

\section{Competing interests}

The authors declare that they have no competing interests.

\section{Author details}

${ }^{1}$ QIMR Berghofer Medical Research Institute, Brisbane, QLD 4029, Australia. ${ }^{2}$ Australian Infectious Disease Research Centre, GVN Center of Excellence, Brisbane, QLD 4029 and 4072, Australia.

Received: 10 February 2021 Accepted: 27 May 2021

Published online: 09 June 2021

\section{References}

1. Santos IA, Grosche VR, Bergamini FRG, Sabino-Silva R, Jardim ACG. Antivirals against coronaviruses: candidate drugs for SARS-CoV-2 treatment? Front Microbiol. 1818;2020:11.

2. Elshabrawy HA. SARS-CoV-2: an update on potential antivirals in light of SARS-CoV antiviral drug discoveries. Vaccines (Basel). 2020;8:335.

3. Pillaiyar T, Wendt LL, Manickam M, Easwaran M. The recent outbreaks of human coronaviruses: a medicinal chemistry perspective. Med Res Rev. 2021;41:72-135

4. Teoh SL, Lim YH, Lai NM, Lee SWH. Directly acting antivirals for COVID-19: where do we stand? Front Microbiol. 1857;2020:11.

5. Luo H, Zhao M, Tan D, Liu C, Yang L, Qiu L, Gao Y, Yu H. Anti-COVID-19 drug screening: frontier concepts and core technologies. Chin Med. 2020;15:115.

6. Wang M, Cao R, Zhang L, Yang X, Liu J, Xu M, Shi Z, Hu Z, Zhong W, Xiao $G$. Remdesivir and chloroquine effectively inhibit the recently emerged novel coronavirus (2019-nCoV) in vitro. Cell Res. 2020;30:269-71.

7. Williamson BN, Feldmann F, Schwarz B, Meade-White K, Porter DP, Schulz J, van Doremalen N, Leighton I, Yinda CK, Perez-Perez L, et al. Clinical benefit of remdesivir in rhesus macaques infected with SARS-CoV-2. Nature. 2020:585:273-6.

8. Wang Y, Zhang D, Du G, Du R, Zhao J, Jin Y, Fu S, Gao L, Cheng Z, Lu Q, et al. Remdesivir in adults with severe COVID-19: a randomised, doubleblind, placebo-controlled, multicentre trial. Lancet. 2020;395:1569-78.

9. Beigel JH, Tomashek KM, Dodd LE, Mehta AK, Zingman BS, Kalil AC, Hohmann E, Chu HY, Luetkemeyer A, Kline S, et al. Remdesivir for the treatment of Covid-19_final report. N Engl J Med. 2020;383:1813-26.

10. Pizzorno A, Padey B, Dubois J, Julien T, Traversier A, Duliere V, Brun P, Lina B, Rosa-Calatrava M, Terrier O. In vitro evaluation of antiviral activity of single and combined repurposable drugs against SARS-CoV-2. Antivir Res. 2020;181:104878.

11. Touret F, Gilles M, Barral K, Nougairede A, van Helden J, Decroly E, de Lamballerie X, Coutard B. In vitro screening of a FDA approved chemical library reveals potential inhibitors of SARS-CoV-2 replication. Sci Rep. 2020;10:13093

12. Caly L, Druce JD, Catton MG, Jans DA, Wagstaff KM. The FDA-approved drug ivermectin inhibits the replication of SARS-CoV-2 in vitro. Antiviral Res. 2020;178:104787.

13. Liu J, Cao R, Xu M, Wang X, Zhang H, Hu H, Li Y, Hu Z, Zhong W, Wang M. Hydroxychloroquine, a less toxic derivative of chloroquine, is effective in inhibiting SARS-CoV-2 infection in vitro. Cell Discov. 2020;6:16.

14. Hoffmann M, Mösbauer K, Hofmann-Winkler H, Kaul A, Kleine-Weber H, Krüger N, Gassen NC, Müller MA, Drosten C, Pöhlmann S. Chloroquine does not inhibit infection of human lung cells with SARS-CoV-2. Nature. 2020:585:588-90.

15. Elavarasi A, Prasad M, Seth T, Sahoo RK, Madan K, Nischal N, Soneja M, Sharma A, Maulik SK. Shalimar, Garg P: Chloroquine and Hydroxychloroquine for the Treatment of COVID-19: a Systematic Review and Metaanalysis. J Gen Intern Med. 2020;35(11):3308-14.

16. Khuroo MS. Chloroquine and hydroxychloroquine in coronavirus disease 2019 (COVID-19). Facts, fiction and the hype: a critical appraisal. Int J Antimicrob Agents. 2020;56:106101.

17. FDA Revokes Emergency Use Authorization for Chloroquine and Hydroxychloroquine (June 15, 2020). https://www.fda.gov/media/138945/down oad.

18. Updike SJ, Eichman PL. Infectious mononucleosis treated with chloroquine. A double-blind study of 40 cases. Am J Med Sci. 1967:254:69-70.

19. Tricou V, Minh NN, Van TP, Lee SJ, Farrar J, Wills B, Tran HT, Simmons CP. A randomized controlled trial of chloroquine for the treatment of dengue in Vietnamese adults. PLoS Negl Trop Dis. 2010;4:e785.

20. Rodrigo C, Fernando SD, Rajapakse S. Clinical evidence for repurposing chloroquine and hydroxychloroquine as antiviral agents: a systematic review. Clin Microbiol Infect. 2020;26:979-87.

21. Roques $P$, Thiberville SD, Dupuis-Maguiraga L, Lum FM, Labadie K, Martinon F, Gras G, Lebon P, Ng LFP, de Lamballerie X, Le Grand R. Paradoxica effect of chloroquine treatment in enhancing Chikungunya virus infection. Viruses. 2018;10:268.

22. Dowall SD, Bosworth A, Watson R, Bewley K, Taylor I, Rayner E, Hunter L, Pearson G, Easterbrook L, Pitman J, et al. Chloroquine inhibited Ebola virus replication in vitro but failed to protect against infection and disease in the in vivo guinea pig model. J Gen Virol. 2015:96:3484-92.

23. Paton NI, Lee L, Xu Y, Ooi EE, Cheung YB, Archuleta S, Wong G, WilderSmith A. Chloroquine for influenza prevention: a randomised, doubleblind, placebo controlled trial. Lancet Infect Dis. 2011;11:677-83.

24. Smee DF, Morrison AC, Barnard DL, Sidwell RW. Comparison of colorimetric, fluorometric, and visual methods for determining anti-influenza ( $\mathrm{H} 1 \mathrm{~N} 1$ and $\mathrm{H} 3 \mathrm{~N} 2)$ virus activities and toxicities of compounds. J Virol Methods. 2002;106:71-9.

25. Ishiyama M, Tominaga H, Shiga M, Sasamoto K, Ohkura Y, Ueno K. A Combined assay of cell vability and in vitro cytotoxicity with a highly water-soluble tetrazolium salt, neutral red and crystal violet. Biol Pharm Bull. 1996;19:1518-20.

26. Behrmann T, Brunner A, Daugelat S, Perrin M, Phyu S, Taillens C, Wee HL. Regulatory compliance of a BSL-3 laboratory unit in a drug discovery environment. Appl Biosaf. 2007;12:220-38.

27. Houston R, Sekine S, Sekine Y. The coupling of translational control and stress responses. J Biochem. 2020;168:93-102.

28. Girardin SE, Cuziol C, Philpott DJ, Arnoult D. The elF2alpha kinase HRI in innate immunity, proteostasis and mitochondrial stress. FEBS J. 2021;288:3094-107.

29. Vind AC, Genzor AV, Bekker-Jensen S. Ribosomal stress-surveillance: three pathways is a magic number. Nucleic Acids Res. 2020;48:10648-61.

30. Eiermann N, Haneke K, Sun Z, Stoecklin G, Ruggieri A. Dance with the devil: stress granules and signaling in antiviral responses. Viruses. 2020;12:E984.

31. Pierre P. Integrating stress responses and immunity. Science. 2019;365:28-9.

32. Dalet A, Arguello RJ, Combes A, Spinelli L, Jaeger S, Fallet M, Vu Manh TP, Mendes A, Perego J, Reverendo M, et al. Protein synthesis inhibition and GADD34 control IFN-beta heterogeneous expression in response to dsRNA. EMBO J. 2017;36:761-82.

33. van den Worm SH, Knoops K, Zevenhoven-Dobbe JC, Beugeling C, van der Meer Y, Mommaas AM, Snijder EJ. Development and 
RNA-synthesizing activity of coronavirus replication structures in the absence of protein synthesis. J Virol. 2011;85:5669-73.

34. Fulda S, Gorman AM, Hori O, Samali A. Cellular stress responses: cell survival and cell death. Int J Cell Biol. 2010;2010:214074.

35. Sionov RV, Haupt $\mathrm{Y}$. The cellular response to p53: the decision between life and death. Oncogene. 1999;18:6145-57.

36. Pietenpol JA, Stewart ZA. Cell cycle checkpoint signaling: cell cycle arrest versus apoptosis. Toxicology. 2002;181-182:475-81.

37. Amarilla AA, Sng J, D, J, Parry R, Deerain JM, Potter J, R., Setoh YX, Rawle DJ, Le TT, Modhiran N, Wang $X$ et al. A versatile reverse genetics platform for SARSCoV-2 and other positive-strand RNA viruses. Nat Commun. 2021. https://doi.org/10.1038/s41467-021-23779-5.

38. Schmidtke M, Schnittler U, Jahn B, Dahse HM, Stelzner A. A rapid assay for evaluation of antiviral activity against coxsackie virus B3, influenza virus A, and herpes simplex virus type 1. J Virol Methods. 2001;95:133-43.

39. Toelzer C, Gupta K, Yadav SKN, Borucu U, Davidson AD, Kavanagh Williamson M, Shoemark DK, Garzoni F, Staufer O, Milligan R, et al. Free fatty acid binding pocket in the locked structure of SARS-CoV-2 spike protein Science. 2020;370:725-30.

40. Yao X, Ye F, Zhang M, Cui C, Huang B, Niu P, Liu X, Zhao L, Dong E, Song C, , et al. In vitro antiviral activity and projection of optimized dosing design of hydroxychloroquine for the treatment of severe acute respiratory syndrome coronavirus 2 (SARS-CoV-2). Clin Infect Dis. 2020;71:732-9.

41. Ku HC, Cheng CF. Master regulator activating transcription factor 3 (ATF3) in metabolic homeostasis and cancer. Front Endocrinol (Lausanne). 2020;11:556

42. Hou YJ, Okuda K, Edwards CE, Martinez DR, Asakura T, Dinnon KH III, Kato T, Lee RE, Yount BL, Mascenik TM, et al. SARS-CoV-2 reverse genetics reveals a variable infection gradient in the respiratory tract. Cell. 2020;182:429-46.

43. Chu H, Chan JF, Yuen TT, Shuai H, Yuan S, Wang Y, Hu B, Yip CC, Tsang JO, Huang $X$, et al. Comparative tropism, replication kinetics, and cell damage profiling of SARS-CoV-2 and SARS-CoV with implications for clinical manifestations, transmissibility, and laboratory studies of COVID-19: an observational study. Lancet Microbe. 2020;1:e14-23.

\section{Publisher's Note}

Springer Nature remains neutral with regard to jurisdictional claims in published maps and institutional affiliations.
Ready to submit your research? Choose BMC and benefit from:

- fast, convenient online submission

- thorough peer review by experienced researchers in your field

- rapid publication on acceptance

- support for research data, including large and complex data types

- gold Open Access which fosters wider collaboration and increased citations

- maximum visibility for your research: over $100 \mathrm{M}$ website views per year

At BMC, research is always in progress.

Learn more biomedcentral.com/submissions 